\title{
Reterritorialising Social Media: Indigenous People Rise Up
}

\section{Alex Wilson}

University of Saskatchewan

alex.wilson@usask.ca

\section{Bronwyn Carlson}

Macquarie University

\section{Acushla Sciascia}

Independent Researcher

Social media is transforming the way Indigenous peoples interact and connect with each other at a local, regional, national and global level. Facebook and other social media facilitate this interaction and allow users to maintain relationships across vast distances and time zones, thereby increasing social and political connectivity and impact (Carlson 2013). Indeed, social media users transcend time and space, yet they produce content, set up links and connect communities of practice. There is now a constantly networked world in every dimension of human experience. Social movements, like every other aspect of life, are becoming increasingly reliant on online networking and information sharing. Researchers are beginning to examine the use of social media for political communication and social movements (Carlson \& Frazer 2016). Generally, however, such research has focused on movements that have received attention from mainstream media, (such as the \#OccupyWallStreet movement for example) whereas Indigenous activism, does not always receive such attention.

Even though Indigenous populations worldwide are avid social media users, Indigenous activism and social media research has yet to gain any real traction in academia. The rapid rise of the use of social media as a means of social, cultural and political interaction among Indigenous peoples and groups is an intriguing development. While this is not to suggest there is no digital inequality, it does counter any assumptions that Indigenous peoples may have little interest in the possibilities of technology and the online environment (Carlson \& Frazer 2015). Social media as a 'new frontier' is where Indigenous peoples are busy interacting and networking in what can be argued as a cultural and political reterritorialisation of social media spaces (Carlson 2013).

The power and potential of social media to promote Indigenous movements on a global level is now manifesting. In the US, the Sioux people of North Dakota demonstrated effectivelythough not yet successfully-against the development of an oil pipeline that would run through traditional homelands. Social media is being deployed to gather a global audience of allies who oppose the development for both Indigenous justice and climate justice reasons. In Australia, led by Aboriginal activist Sam Cook, a movement against the forced closure of Aboriginal communities was focused by the hashtag \#SOSBlakAustralia. Through effectively using Facebook and Twitter in combination with on-the-streets protesting, the movement sustained a global audience even while traditional forms of media actively sought to ignore or undermine the movement (Carlson \& Frazer 2016).

To increase Māori political engagement the Mana Movement (formally known as the Mana Party) actively used Facebook to raise awareness of political issues and to engage Māori now living in Australia. In what O'Carroll (2013) refers to as "the virtual marae" (a communal meeting ground) Māori are using social media to maintain kinship relationships and advocate for maintaining language and other cultural practices around the world. In Hawaii, Indigenous Hawaiians have engaged in a protracted protest against the redevelopment of a major telescope on top of the dormant volcano Mauna Kea, which is considered a significant sacred site (Kamelamela 2016). While protesters used mass blockages and sit-ins to prevent the development, the story of the protests was shared virally through social media-particularly Instagram-where photos of the protests were shared by high profile celebrities drawing global attention to the campaign. 
In Canada the movement Idle No More has used social media to highlight issues facing First Nations, Metis and Inuit people. The movement began following the Harper government passing Bill C-45, which sought to divest First Nations sovereign command of lands and waterways. The movement, utilising the hashtag \#IdleNoMore, has used social media to promote environmental justice issues globally (McMillan, Young \& Peters 2013). Other Indigenous groups, such as 'Aotearoa in Support of Idle No More' and 'Protect Mauna Kea' have shown Indigenous solidarity with the movements. Thus, Indigenous groups have deployed social media effectively in diverse efforts to coordinate collective political practice and express political will in a climate where their voices are often ignored.

In this Special Section of the Australasian Journal of Information Systems (AJIS) entitled, "Research on Indigenous use of Information and Communication Technologies: Reterritorialising Social Media: Indigenous People Rise Up" authors describe specific aspects of "reterritorialisation". Mainstream media cannot necessarily be counted upon to take interest in issues specific to or of concern to Indigenous peoples. Social media however, is providing the means whereby Indigenous people can "reterritorialise" and "Indigenise" the information and communication space. The ability to create international solidarity as well as elevating Indigenous issues to a global platform remain key strengths for Indigenous activism. The level of visibility social media has given Indigenous issues is unprecedented.

This special section begins with a powerful poem entitled, "Social Media Exploration 1.1" written by Māori poet, performer and activist Te Kahu Rolleston. The poem was written especially for the 2015 international symposium, 'Reterritorialising Social Media: Indigenous People Rise Up' which was held at the University of Wollongong, NSW Australia and was hosted by The Forum for Indigenous Research Excellence (FIRE). The video of Rolleston's performance can be accessed via The Journal of Global Indigeneity at the following link, http://ro.uow.edu.au/jgi/vol1/iss2/9/).

Led by Indigenous Australian journalist and scholar Jack Latimore, David Nolan, Margaret Simons, Elyas Khan provide a theoretical ground for considering the inherited and shifting spaces of Indigenous media representation in their paper, "Reassembling the Indigenous Public Sphere". Noting that more Indigenous people are choosing digital media as a source of news this paper discusses the rise of Indigenous news outlets that cover Indigenous issues and events. This paper introduces the Wakul App - software infrastructure tailored for connecting Indigenous communities and highlighting the issues that matter to Indigenous people as opposed to what is being covered by mainstream media.

Following, Native American scholar Marisa Duarte's article "Connected Activism: Indigenous Uses of Social Media for Shaping Political Change" explores the use of digital tactics in social and political campaigns. Drawing on three case studies, Duarte compares the kinds of community knowledge work that takes place as part of any online Indigenous rights movements. Exploring EZLN, Idle No More, and the ongoing Rio Yaqui water rights movement Duarte reveals the significance of political and social connections forged via digital tools and in doing so reveals that Indigenous movements are always grounded in Indigenous ways of knowing and understanding the world.

Indigenous Australian scholar Bronwyn Carlson and colleagues Lani Jones, Michelle Harris, Nelia Quezada and Ryan Frazer investigate the ways in which Indigenous Australians respond individually, and collectively, to racial vilification by means of social media sites in their paper, "Trauma, Shared Recognition and Indigenous Resistance on Social media". They argue that Indigenous people collectively experience a sense of anger and frustration when traumatic events in the public domain act as reminders of ongoing colonialism. Drawing on Sara Ahmed's (2004) notion of "affective economies" this paper unpacks the politics of pain, shame and pride in the aftermath of both the Four Corners program and the Bill Leak cartoon. Importantly, this paper also focuses on the Indigenous led \#IndigenousDads Twitter campaign that emerged in response to these events and demonstrates the use of social media in the ongoing resistance to colonial narratives. 
In her paper "Protecting Oak Flat: Acts of Resilience as Observed Through Digital Activism" Native American Graduate Student Nicholet Deschine Parkhurst highlights the ongoing battle to protect lands and resources. This paper focuses on a specific case study of Oak Flat and how Native American activist deployed social media to protest the destruction of sacred lands by mining companies. In this case, as with others, efforts included a combination of on-theground efforts, online efforts, solidarity efforts, and legislative support efforts.

The paper, "The Whiteness of Redmen: Indigenous Mascots, Social Media and an Antiracist Intervention" authored by Idle No More co-founder Sheelah McLean, Cree scholar Alex Wilson and Cree activist Erica Lee presents the story and analysis of how the grassroots movement Idle No More's (INM) social media power contributed to the successful 'retirement' of a racist high school mascot. McLean, Wilson and Lee, all INM organisers, connect social media and anti-racist education, providing a way for Indigenous peoples to intervene and reclaim digital and real time space and representations.

Eric Otenyo's article “Being Left Behind Amidst Africa's Rising Imagery: The Maasai in the World of Information and Communication Technologies (Icts)" provides and overview of the exploitation of Maasai imagery and culture providing a counter narrative to the idea of "Africa rising". Otenyo reminds us that although Indigenous groups are active social media users, governments also use social media to present a particular reality of Indigenous people. In the example of Maasai people, the digital divide is very real with many Maasai marginalised and life chances worsening rather than improving. The way Maasai people and communities are represented on social media is often out of the control of Maasai themselves. However, Maasai are utilising online platforms to campaign against injustices.

Demonstrating how Indigenous people use humour as a strategy of resistance scholar Jeff Berglund showcases the work of Native American comedy troupe The 1491s in his paper "Go Cry Over Someone Else's Tragedy': The YouTube Activism of The 1491s”. As Berglund argues, the 1491s have successfully used social media to reach a global audience and to advocate for positive change for Native American people and communities. Using humour to challenge mainstream representation of Native American people the comedy troupe have been successful in attracting vast attention to their political stance on a variety of topics including the recent \#NoDAPL movement.

Indigenous Australian graduate student Andrew Farrell discusses the use of social media by Indigenous LBGTQI communities in his paper, "Archiving The Aboriginal Rainbow: Reflections On Building An Aboriginal LBGTQI Portal And Archive Online". Drawing on the work of Leesa Watego, who conceptualised online blogging as a kind of "midden" (Watego 2015) this paper explores the layers of knowledges that are shared and stored online via social media. This paper highlights the need for a counter narrative to the negative representation of the LBGTQI community and the power of social media in enabling an "Indigenising" of the online world of Blogging.

In summary, the articles in this special section challenge the reader to engage with on the ground activists and educators who seek to protect Indigenous and environmental rights on our traditional territories through the use of the modern technologies of social media. Although not necessarily designed for facilitating political activism, social media has become a common entry point for many Indigenous led campaigns. It has become a wellspring of new forms of political expression and action, which appear to complement rather than supplant more traditional forms of activism (Bennett \& Segerberg 2012). Social media is now undoubtedly a great force for political organisation and transformation allowing for the amplification of Indigenous voices. These voices, as represented in this special section, reaffirm Indigenous sovereignty and connections to ancestral homelands. Indigenous people indeed are reterritorialising social media and as always will continue to Rise Up. 


\section{References}

Bennett, L. W. \& Segerberg, A. (2012) The logic of connective action: Digital media and the personalization of contentious politics. Information, Communication \& Society, 15(5): 739-768.

Carlson, B. (2013) The 'new frontier': Emergent Indigenous identities and social media. In Harris, M., Nakata, M. \& Carlson, B. (Eds.), The Politics of Identity: Emerging Indigeneity, University of Technology Sydney E-Press: Sydney.

Carlson, B. \& Frazer, R. (2015) "It's like going to a cemetery and lighting a candle": Aboriginal Australians, Sorry Business and social media. AlterNative: An International Journal of Indigenous Peoples, 11(3): 211-224.

Carlson, B. \& Frazer, R. (2016) Indigenous activism and social media: The global response to \#SOSBLAKAUSTRAIA. In McCosker, A., Vivienne, S., \& Johns, A. (Eds.), Rethinking Digital Citizenship: Control, Contest and Culture, Rowman and Littlefield International: England.

Kamelamela, K. (2016) The protect Mauna Kea movement: Since before the overthrow in 1893. Journal of Global Indigeneity, 1(2). Available at, http://ro.uow.edu.au/jgi/vol1/iss2/5/

McMillan, L.J., Young, J. \& Peters, M. (2013) Commentary: The 'idle no more' movement in eastern Canada. Canadian Journal of Law and Society, 28(3): 429-431.

O'Carroll, A. D. (2013) Virtual whanaungatanga. Māori utilising social networking sites to attain and maintain relationships. AlterNative: International Journal of Indigenous People, 9(3): 230-245.

Watego, L. (2015) Even the Activist's Gotta Eat: Taking Ownership, Building Platforms. Journal of Global Indigeneity, 1(2). Available at: http://ro.uow.edu.au/jgi/vol1/iss2/7/

Copyright: (C) 2017 Wilson, Carlson \& Sciascia. This is an open-access article distributed under the terms of the Creative Commons Attribution-NonCommercial 3.0 Australia License, which permits non-commercial use, distribution, and reproduction in any medium, provided the original author and AJIS are credited.

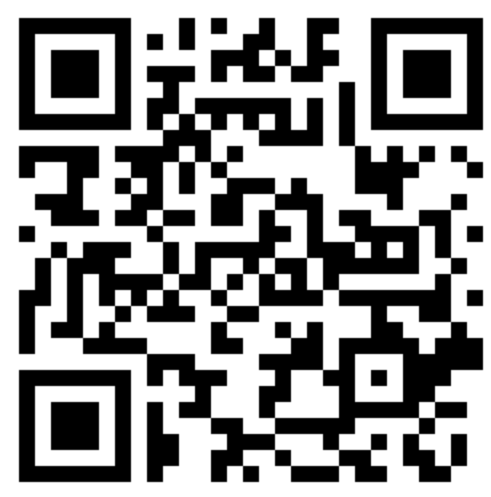

